\title{
Tolerance of abuse within Mexican adolescent relationships
}

\author{
Lourdes Cortés Ayala', Carolina Bringas Molleda², Cristina Estrada Pineda ${ }^{3}$, M Ángeles Antuña Bellerín ${ }^{4}$, \\ Luis Rodríguez Franco ${ }^{4}$ and Francisco Javier Rodríguez Diaz ${ }^{5,6^{*}}$
}

\begin{abstract}
Violence in interpersonal relationships in young people has been the subject of several studies in recent years. Studies of dating violence show that one of the resources available for the young to help perceive and distinguish abusive or violent behaviour is an indicator which increases the ability to recognise as well as confront the reality of abuse. Certain violent behaviour however can be perceived as non-abusive, where the victim and the aggressor can share an abnormal view of the relationship in which possession, jealousy and exclusivity are considered significant elements within the relationship. The objective of this study is to understand and establish the levels of aggravation (degree of tolerance) towards violent behaviour in relationships of engaged adolescent Mexicans affected by abuse, by considering gender and level of perception of abuse as variables. The sample was formed of 3304 young Mexican students between the ages of 13 and 22, containing 1432 boys and 1872 girls, 1383 pursuing university studies, whereas the remaining 1921 were pre-university students. CUVINO was administered in order to determine the abusive conduct and levels of discomfort (tolerance), which allowed us to observe that the highest levels of discomfort, greater than those caused by any other kind of abuse, are experienced by women, especially regarding sexual victimization within the category of those non-abused women that presented a lower level of tolerance. This finding led us to identify, as a major risk factor, those men and women with a high level of tolerance, who did not perceive themselves as having been abused.
\end{abstract}

Keywords: Tolerance, Relationship abuse, Adolescence, Abuse perception, Gender

\section{Background}

The study of dating violence has received a lot of attention recently, both for its prevalence rate as well as for the repercussions for those who suffer from this violence (Cho et al. 2014; Ruiz-Hernández et al. 2015; Muñoz-Rivas et al. 2007; Rodríguez-Franco et al. 2016; Rodríguez-Franco et al. 2010; Gómez et al. 2014). Studies show that one of the resources available for the young to help perceive and distinguish abusive or violent behaviour is an indicator which increases the ability to recognise as well as confront the reality of abuse (Rodríguez-Franco et al. 2010; Arce et al. 2015).

Certain violent behaviour however can be perceived as non-abusive, where the victim and the aggressor can share an abnormal view of the relationship in which

\footnotetext{
* Correspondence: gallego@uniovi.es

${ }^{5}$ Universidad de Oviedo, Oviedo, Spain

${ }^{6}$ Facultad de Psicología, Plaza Feijóo, s/n. Despacho 202, 33003 Madrid, Spain Full list of author information is available at the end of the article
}

possession, jealousy and exclusivity are considered significant elements within the relationship (Hernando et al. 2012; López-Cepero et al. 2015). In turn, in many cases, the tolerance of abusive behaviour through means of avoidance or trivialisation of the act can contribute towards the victim maintaining a 'barely healthy' relationship (Dunham and Senn 2000) and towards the establishment of the perception that nobody is being abused.

Diverse studies refer to a variety of factors related to the classification of violent behaviour as being abusive: attitudes towards violence in general (Antle et al. 2011; Novo et al. 2016); childhood experiences of abuse (Lichter and McCloskey, 2004); feelings of guilt (Kahn et al. 2003); and the defence the victim may use minimise and justify abusive conduct or violence in order to protect the positive aspects of such a relationship (Harned 2005). Stereotypes play a major role, such as corroborating the belief that sexual coercion and abusive 
situations are acts exclusively perpetrated by a stranger and not by their own partner (Kahn et al. 2003; Littleton et al. 2009), being differently judged in terms of the perpetrator responsibility by males and females (Arce et al. 2000).

Kahn et al. (2003) and Harned (2005) have addressed the issue that consent or tolerance seem to play a key role in the labelling (or recognition) of a situation as abusive. Other studies show that university students do not perceive coercive sexual tactics as problematic, especially if they imply little or no physical force. This leads to such behaviour being seen as socially acceptable and increases the probability of it occurring again in the future. Similar conclusions regarding the tolerance of violence and its reoccurrence are given within American (McDonell et al. 2010), Canadian (Connolly et al. 2010) and Mexican (Sánchez and Solís 2007) publications.

In turn, studies on Mexican populations (Cortés et al. 2014) have shown that a significant proportion of adolescents and youngsters (88\%) do not perceive or recognise such abusive behaviour. In many cases, the incapacity to perceive and identify violent behaviour within a relationship has been related with subsequent experiences of victimization (Anderson and KobekPezzarossi 2011; Rodríguez-Franco et al. 2012), thereby demonstrating that higher levels of tolerance are associated with negative attitudes towards making an official complaint (Mugoya et al. 2015; Gracia et al. 2010).

The 'normalisation' and tolerance towards expressions of violence between partners not only has consequences affecting the perception of abuse but can also cause manifestations in the health of the youths and in their stable and/or aggressive emotional relationships in the future(Muñoz-Rivas et al. 2007; Shorey et al. 2015).

In turn, it is confirmed that the violence manifested in emotional relationships of young people today can be bidirectional, meaning that it is practised simultaneously by men as well as women (Rey-Anacona 2013). Studies on the young American population show that women practise acts of violence and psychological abuse more than men (Sears et al. 2007). Straus (2004), in an international study, found a higher percentage of women than men as aggressors.

Studies on Mexican youth also confirm this symmetry regarding aggression perpetrated by both sexes (González et al. 2010; Ramírez and Smithey 2008). In response, the tolerance of abusive conduct within relationships leads to the participants being protective, avoidant or minimising, and therefore contributes towards the victim maintaining or ending the abusive relationship. The study of violence within the relationships of engaged couples in Mexico has generated progressive interest in recent years (Rojas-Solís 2013). Questionnaires and national studies regarding the prevalence of violence within relationships of engaged couples (ENDIREH 2011; ENVINOV 2008) offer results similar to those obtained in other countries: up to $76 \%$ of adolescent males and females between the ages of 15 and 24 in an engaged relationship have suffered emotionally violent abusive behaviour, $15 \%$ have suffered physical violence and $16.5 \%$ sexual violence. Additionally, with regard to sexual violence, a larger majority of women (46\%) do not mention the abuse to anyone as they consider it 'unimportant', and with regard to physical violence, as many boys and girls tend to trivialise the episodes of aggression, perceiving them as 'normal' within these types of relationships. Thus, the importance surrounding the perception of abuse (Cortés et al. 2014; Rodríguez-Franco et al. 2012) establishes a partner's behaviour as 'acceptable' or 'not serious enough' which can lead to a lower probability of the victim deciding to actively ask for help or seek a positive intervention (Gracia et al. 2010).

In turn, engaged couples have an increased probability of becoming involved in a violent relationship in the future (Gómez 2011; O’Leary and Slep 2011; Whitaker et al. 2010).Studies involving university students show that the majority of relationships have at least some level of psychological aggression, with prevalence rates between 70 and 80\% (Cornelius, Shorey, and Beebe 2010) and that the levels of psychological aggression and victimization within an abusive relationship are comparable for both men and women (Taft et al. 2010).

Hence, it is important to establish the early detection of violence within a relationship in order to design effective interventions so that victims can be recognised as such (López-Cepero et al. 2015; Rodríguez-Franco et al. 2010). Therefore, the objective of this study is to identify and establish the various levels of distress (degree of tolerance) linked to violent behaviour within relationships of engaged Mexican couples, while considering variables, such as gender and the type of perception of the abuse, as modulators.

\section{Methods \\ Participants}

The sample was formed of 3304 young Mexican students between the ages of 13 and $22(M=17.47, \mathrm{SD}=2.28)$, containing 1432 boys (43.3\%) and 1872 girls (56.7\%), with $41.9 \%(N=1383)$ pursuing university studies, whereas the remaining 1921 which represented the $58.1 \%$, were preuniversity students, in secondary education $(N=659$, $19.9 \%)$ and further education $(N=1262,38.2 \%)$. The distribution of the gender variable in terms of the level of study showed 847 boys $(59.1 \%$ of the total number of boys) and 1074 girls (57.4\% of the total number of girls) attending pre-university courses, whereas at a university level, the female population 
was made up of the remaining 798 girls (42.6\%) and 585 (40.9\%) of the boys.

\section{Instruments and variables}

First, the socio-demographic data was collected through an ad hoc questionnaire, whose main objective was to obtain pertinent information relevant to each participant, such as age, gender, level of study, social class and income level. The CUVINO questionnaire, related to violence between partners, was then applied: a sampling of 42 items which reflects various types of abusive behaviour. The participants responded by indicating to what extent they had ever suffered from any of these types of abuse and to what extent they would have suffered in the cases where they had never been subject to any of these types of abuse. The Likert scale was used, which ranges from 0 (never) to 4 (almost always).

The 42 items were grouped into eight factors of behavioural violence: Detachment, Humiliation, Sexual, Coercion, Physical, Gender, Emotional Punishment and Instrumental. The results were analysed with respect to the self-awareness of the abuse, based on a group of responses to the following three questions: Have you ever felt abused? Do you feel or have you ever felt scared of your partner? Do you feel or have you ever felt trapped within your relationship? Each of these questions offered two possible answers: Yes or No. This made it possible to classify each sample into three categories depending on the participant's perception of abuse: the first included those who had felt they had been abused (abused (A)), the second was made up of those who indicated they had never been abused, nor felt fear or trapped within their relationship (non-abused (NA)), and the third group was made up by those who felt they had never been abused, however, at some moment during their relationship, had been afraid of their partner or had felt trapped; these will be referred to as nonperceived abuse (non-perceived abused (NPA)).

\section{Procedure and data analysis}

The selection of the data centres was carried out on the basis of a non-pro-ballistic approach. Once the objective of the investigation had been explained to the central management team, and permission and informed consent of the participants had been obtained, tests began to be administered. Participants had been previously informed regarding the anonymity and the confidentiality of their answers so that they would feel comfortable giving information and continuing with the research.

The data was processed using the SPSS 19 statistics package. The initial task was to obtain a contrast of averages, through the use of Student's $t$ test for independent samples with the objective of establishing the differences between genders regarding the level of tolerance for each type of victimization, while at the same time calculating the depth of the effects from abuse. To this end, Cohen's d (Cohen 1988) was applied, in which scores inferior to 0.20 indicate a negligible effect; those between 0.20 and 0.49 , a low effect; those from 0.50 to 0.79 , a medium effect; and anything above 0.80 indicates a major effect. We then proceeded to calculate the existence of various sexual differences that existed within each of the three groups of perceivably abused youths that made up our study.

These differences between the levels of discomfort within each of the three groups of perceivably abused youths were then calculated through the application of ANOVA, in an independent form for each gender. To this end, equality in the level of variance had not been assumed, and Dunnet's T3 statistical analysis enabled us to determine the existence of a variety of levels of tolerance of each of the two genders regarding the type of abuse perceived.

Finally, the ranges of the scores related to tolerance factors were established and the average values related to factors of considered abuse were calculated, and were weighted in terms of the number of items that made up each factor in such a way that these scores were comparable. In accordance with these results, the percentages that constitute the maximum and minimum scores within each set of the factors could then be established.

\section{Results}

The results show (see Table 1) the statistically significant differences between genders across all the factors of abuse. In all cases, a higher degree of distress exists among females, that is, a lower level of tolerances shown towards each type of abuse considered in CUVINO. Regarding the degree of the effects, Gender and Sexual Violence display very high scores (above 0.80 ), whereas the remaining cases lie within the medium range.

With the objective of establishing the significance of self-perception of abuse within each gender, three possible conditions for the participants of this study were considered: abused (A), non-abused (NA) and nonperceived abuse (NPA). The results obtained by grouping these samples into these categories (Table 2) indicate various differences between males and females: in all cases, women showed a significantly higher level of distress (lower tolerance), and in the majority of cases, a medium effect size (ES); low ES results were obtained for the Emotional Punishment factor (0.42) in the subsample of abused subjects, and the highest results were those of where Sexual Abuse had taken place (ES 1.03), (self-perception regarding the differences surrounding sexual abuse resulted in considerably different opinions between males and females within the NPA group). 
Table 1 Averages and contrasts of the mean grade of $t$, which measures the level of distress within each factor of abuse for each gender

\begin{tabular}{|c|c|c|c|c|c|c|}
\hline \multirow[t]{2}{*}{ Factors } & \multirow[b]{2}{*}{$\begin{array}{l}\text { Men } \\
M(\mathrm{SD})\end{array}$} & \multirow[b]{2}{*}{$\begin{array}{l}\text { Women } \\
M(\mathrm{SD})\end{array}$} & \multirow[b]{2}{*}{$t$} & \multirow[b]{2}{*}{$d f$} & \multirow[b]{2}{*}{$p$} & \multirow[b]{2}{*}{$\eta 2$} \\
\hline & & & & & & \\
\hline Detachment & $15.90(7.68)$ & $21.06(6.99)$ & -19.82 & 2902.10 & 0.000 & 0.66 \\
\hline Humiliation & $16.00(8.76)$ & $21.88(7.93)$ & -19.84 & 2892.00 & 0.000 & 0.66 \\
\hline Sexual & $9.24(6.83)$ & $18.21(6.91)$ & -37.12 & 3077.49 & 0.000 & 1.09 \\
\hline Coercion & $11.99(6.02)$ & $16.45(5.95)$ & -21.12 & 3043.01 & 0.000 & 0.70 \\
\hline Physical & $11.15(6.47)$ & $15.85(6.08)$ & -21.17 & 2957.92 & 0.000 & 0.70 \\
\hline Gender & $9.05(5.60)$ & $14.22(5.57)$ & -26.27 & 3052.52 & 0.000 & 0.84 \\
\hline Emotional Punishment & $5.96(3.50)$ & $8.10(3.48)$ & -17.35 & 3054.37 & 0.000 & 0.58 \\
\hline Instrumental & $6.10(3.95)$ & $8.66(3.87)$ & -18.52 & 3029 & 0.000 & 0.62 \\
\hline
\end{tabular}

The gender-specific analysis between the three categories of possible abuse related to youths (Table 3) illustrates that for males, there only exists differences between the three categories considered within one of the eight factors of distress regarding abuse (Sexual).
However, the tendency indicates that the levels of distress veer towards being higher within the subgroup of abused youths with the exception of the levels obtained in the Sexual factor (in which the highest level of distress appears with a very slight difference as in the NA

Table 2 Statistics describing the level of distress for the perception of abuse in each of the factors and the level of the observed effect, for each gender

\begin{tabular}{|c|c|c|c|c|c|c|}
\hline Factors & Self-perception & $\begin{array}{l}\text { Men } \\
X(S D)\end{array}$ & $\begin{array}{l}\text { Women } \\
X(S D)\end{array}$ & $t$ & $p$ & $\eta 2$ \\
\hline \multirow[t]{3}{*}{ Detachment } & $A$ & $17.16(7.04)$ & 20.94 (6.36) & -5.287 & 0.000 & 0.55 \\
\hline & NA & 15.69 (7.95) & $21.29(7.23)$ & -15.385 & 0.000 & 0.69 \\
\hline & NPA & $15.87(7.42)$ & 20.70 (6.79) & -11.178 & 0.000 & 0.64 \\
\hline \multirow[t]{3}{*}{ Humiliation } & A & $16.24(7.82)$ & 21.84 (6.92) & -7.098 & 0.000 & 0.72 \\
\hline & NA & 16.16 (8.93) & 22.14 (7.98) & -14.714 & 0.000 & 0.67 \\
\hline & NPA & $15.68(8.77)$ & $21.42(8.21)$ & -11.134 & 0.000 & 0.64 \\
\hline \multirow[t]{3}{*}{ Sexual } & A & $9.57(7.04)$ & $17.52(6.45)$ & -11.297 & 0.000 & 1.03 \\
\hline & NA & $9.59(6.97)$ & 18.59 (6.93) & -27.192 & 0.000 & 1.09 \\
\hline & NPA & $8.62(6.53)$ & 17.84 (7.02) & -22.406 & 0.000 & 1.12 \\
\hline \multirow[t]{3}{*}{ Coercion } & $A$ & $13.04(5.85)$ & 16.52 (5.20) & -6.064 & 0.000 & 0.60 \\
\hline & NA & $11.87(6.28)$ & 16.56 (6.30) & -15.672 & 0.000 & 0.70 \\
\hline & NPA & $11.88(5.63)$ & $16.22(5.60)$ & -12.754 & 0.000 & 0.72 \\
\hline \multirow[t]{3}{*}{ Physical } & $A$ & $11.68(6.05)$ & $15.34(6.20)$ & -5.654 & 0.000 & 0.57 \\
\hline & NA & $11.28(6.54)$ & $16.18(5.86)$ & -16.462 & 0.000 & 0.74 \\
\hline & NPA & $10.80(6.49)$ & 15.48 (6.38) & -11.989 & 0.000 & 0.68 \\
\hline \multirow[t]{3}{*}{ Gender } & $A$ & $9.41(5.36)$ & 14.03 (5.19) & -8.350 & 0.000 & 0.80 \\
\hline & NA & $9.15(5.74)$ & 14.45 (5.57) & -19.630 & 0.000 & 0.85 \\
\hline & NPA & $8.80(5.45)$ & $13.91(5.72)$ & -15.054 & 0.000 & 0.83 \\
\hline \multirow[t]{3}{*}{ Emotional Punishment } & A & $6.22(3.32)$ & $7.67(3.42)$ & -4.046 & 0.000 & 0.42 \\
\hline & NA & $6.04(3.54)$ & $8.34(3.47)$ & -13.817 & 0.000 & 0.62 \\
\hline & NPA & $5.77(3.48)$ & $7.83(3.49)$ & -9.766 & 0.000 & 0.56 \\
\hline \multirow[t]{3}{*}{ Instrumental } & $A$ & $5.84(4.01)$ & $8.12(4.20)$ & -5.224 & 0.000 & 0.53 \\
\hline & NA & $6.21(3.93)$ & $8.92(3.68)$ & -9.956 & 0.000 & 0.67 \\
\hline & NPA & $6.01(3.96)$ & $8.42(4.01)$ & -14.846 & 0.000 & 0.57 \\
\hline
\end{tabular}


Table 3 ANOVA for each factor with regard to the level of tolerance according to the perception of abuse for each gender and for each of the factors of abuse

\begin{tabular}{|c|c|c|c|c|c|c|c|c|c|c|}
\hline \multirow[t]{2}{*}{ Factors } & \multirow[t]{2}{*}{ Self-perception } & \multicolumn{5}{|l|}{ Men } & \multicolumn{3}{|l|}{ Women } & \multirow[b]{2}{*}{$\eta 2$} \\
\hline & & $F(\mathrm{df}: 2)$ & $p$ & & Dunnet's T3 & ES & $F(\mathrm{df}: 2)$ & $p$ & Dunnet's T3 & \\
\hline \multirow[t]{3}{*}{ Detachment } & $A(1)$ & 2.25 & 0.11 & $(1: 2)$ & 1.47 & 0.19 & 1.372 & 0.25 & 0.348 & 0.05 \\
\hline & NA (2) & & & $(2: 3)$ & 0.181 & 0.02 & & & 0.589 & 0.08 \\
\hline & NPA (3) & & & $(1: 3)$ & 1.29 & 0.17 & & & 0.240 & 0.03 \\
\hline \multirow[t]{3}{*}{ Humiliation } & $A(1)$ & 0.52 & 0.59 & $(1: 2)$ & 0.072 & 0.00 & 1.558 & 0.21 & 0.306 & 0.04 \\
\hline & NA (2) & & & $(2: 3)$ & 0.483 & 0.05 & & & 0.721 & 0.09 \\
\hline & NPA (3) & & & $(1: 3)$ & 0.555 & 0.07 & & & 0.414 & 0.05 \\
\hline \multirow[t]{3}{*}{ Sexual } & $A(1)$ & 3.28 & 0.03 & $(1: 2)$ & 0.014 & 0.00 & 3.594 & 0.03 & 1.07 & 0.15 \\
\hline & NA (2) & & & $(2: 3)$ & $0.969^{*}$ & 0.14 & & & 0.744 & 0.10 \\
\hline & NPA (3) & & & $(1: 3)$ & 0.954 & 0.14 & & & 0.326 & 0.05 \\
\hline \multirow[t]{3}{*}{ Coercion } & $A(1)$ & 2.43 & 0.08 & $(1: 2)$ & 1.168 & 0.19 & 0.642 & 0.53 & 0.040 & 0.00 \\
\hline & NA (2) & & & $(2: 3)$ & 0.011 & 0.00 & & & 0.342 & 0.05 \\
\hline & NPA (3) & & & $(1: 3)$ & 1.157 & 0.20 & & & 0.302 & 0.05 \\
\hline \multirow[t]{3}{*}{ Physical } & $A(1)$ & 1.35 & 0.26 & $(1: 2)$ & 0.399 & 0.06 & 3.504 & 0.03 & 0.847 & 0.13 \\
\hline & NA (2) & & & $(2: 3)$ & 0.474 & 0.07 & & & 0.702 & 0.11 \\
\hline & NPA (3) & & & $(1: 3)$ & 0.873 & 0.14 & & & 0.144 & 0.02 \\
\hline \multirow[t]{3}{*}{ Gender } & $A(1)$ & 0.92 & 0.40 & $(1: 2)$ & 0.260 & 0.04 & 1.938 & 0.14 & 0.419 & 0.08 \\
\hline & NA (2) & & & $(2: 3)$ & 0.347 & 0.06 & & & 0.541 & 0.09 \\
\hline & NPA (3) & & & $(1: 3)$ & 0.608 & 0.11 & & & 0.121 & 0.02 \\
\hline \multirow[t]{3}{*}{ Emotional Punishment } & $A(1)$ & 1.37 & 0.25 & $(1: 2)$ & 0.183 & 0.05 & 6.167 & 0.00 & $0.677^{*}$ & 0.19 \\
\hline & NA (2) & & & $(2: 3)$ & 0.272 & 0.08 & & & $0.512^{*}$ & 0.14 \\
\hline & NPA (3) & & & $(1: 3)$ & 0.455 & 0.13 & & & 0.165 & 0.04 \\
\hline \multirow[t]{3}{*}{ Instrumental } & $A(1)$ & 0.76 & 0.47 & $(1: 2)$ & 0.371 & 0.09 & 5.877 & 0.00 & $0.804^{*}$ & 0.20 \\
\hline & NA (2) & & & $(2: 3)$ & 0.204 & 0.05 & & & $0.501^{*}$ & 0.13 \\
\hline & NPA (3) & & & $(1: 3)$ & 0.167 & 0.04 & & & 0.302 & 0.07 \\
\hline
\end{tabular}

group) and Instrumental factor, from which the NA group obtains similar scores to those of the remaining groups.

However, as regards women, the differences between the subgroups of abused youths appear in four of the factors: Sexual, Physical, Emotional Punishment and Instrumental. In this case, the general tendency is that the female NA group obtains results regarding distress that are higher than those of the remaining groups (A and NPA). The results however, offer a negligible level of effect in all cases, with the only exception being the result obtained regarding the behaviour of Instrumental violence: that of a low level of effect for the A and NA groups.

Additionally, the average values of the eight factors have been detailed (Table 4) and weighted in terms of the number of items that constitute each factor, in such a way that they can be compared. At the same time, a range for each factor was devised as well as the percentage for the highest and lowest scores within each factor for each relationship. This permitted us to place a value on the differences between genders: when the three factors in which the highest level of uneasiness exist were selected, both sexes coincided in that they considered Humiliation and Physical Abuse obtained the highest levels; among the males, punishment by Detachment was added, and for the females, the Sexual factor was added. Out of the three factors with the lowest level of distress (or highest level of tolerance), both sexes coincided in that they considered Gender Violence and Emotional Punishment (males included Sexual Abuse and females included Coercion into these categories) to represent the least distressing category.

\section{Discussion and conclusions}

Our studies adopted the dynamics developmental system perspective (Capaldi et al. 2005) as a reference, which concluded that abuse between partners is the result of 
Table 4 Mean values of the weighted factors, range assigned for each factor and the percentage of maximum and minimum scores of each factor

\begin{tabular}{|c|c|c|c|c|c|c|c|c|}
\hline \multirow[t]{2}{*}{ Factors } & \multicolumn{4}{|l|}{ Men } & \multicolumn{4}{|c|}{ Women } \\
\hline & Values & Range & $\%$ Max values & $\%$ Min values & Values & Range & $\%$ Max values & $\%$ Min values \\
\hline Detachment & 2.27 & 2 & 27.1 & 16.2 & 3.01 & 4 & 63.5 & 7.8 \\
\hline Humiliation & 2.29 & 1 & 32.7 & 18.8 & 3.13 & 2 & 69.8 & 9.2 \\
\hline Sexual & 1.54 & 8 & 11.6 & 35 & 3.04 & 3 & 65.2 & 10.2 \\
\hline Coercion & 2.00 & 5 & 13.4 & 16.5 & 2.74 & 7 & 43.9 & 8 \\
\hline Physical & 2.23 & 3 & 26.1 & 20.4 & 3.17 & 1 & 66.5 & 11.3 \\
\hline Gender & 1.81 & 7 & 8.9 & 25.3 & 2.85 & 6 & 43.4 & 10.5 \\
\hline Emotional Punishment & 1.99 & 6 & 9.8 & 19.6 & 2.70 & 8 & 30.3 & 10.7 \\
\hline Instrumental & 2.04 & 4 & 16 & 23.8 & 2.89 & 5 & 43.5 & 13 \\
\hline
\end{tabular}

the contextual and demographic characteristics of both members, the conduct of both members (including socialization experiences) and the patterns of the said relationship as well as the interaction between the partners. Within this perspective, our interest is centred more specifically on the analysis of the attitudes and more particularly on the levels of distress which lead to abusive behaviour within the relationship of an engaged couple.

In addition, a central interest of this study has focused on determining this association within the three groups: those who consider themselves to have been abused (A); those who do not consider to have ever been abused (NA); and finally, the third group (NPA non-perceived abuse), those who do not consider themselves as having been abused although present behavioural signs indicate that they have been abused. The latter group merits special interest, given their lack of awareness of an abusive relationship in which they are the victim, and hence they constitute a group of subjects at great risk, since it is known that the primary prevention strategies probably have not been put into effect and are therefore useless (Mugoya et al. 2015; Rodríguez-Franco et al. 2012).

In general terms, the data presented certain similarities between the forms of victimization: the greatest distress for either men or women was due to their lower tolerance of psychological abuse (Detachment or Humiliation). In the case of males, a lower tolerance of abuse with reference to Coercion and Physical Abuse was observed, whereas for females more often than not, it was Sexual Abuse. On the other hand, the differences found between the sexes regarding the levels of distress considered in the CUVINO factors, showed that women presented a higher level of distress (lower tolerance) than men regarding each and every form of abuse, especially Physical Abuse, Humiliation, Sexual Abuse and Detachment. Bearing this in mind, males displayed some levels of discomfort of a more moderate nature, with their highest levels related to Humiliation, Detachment and Physical Abuse. In contrast, the lowest levels of distress for women were found to be related to the Emotional Punishment and Coercion factors, whereas in men, these were related to Sexual Abuse, Gender Abuse and Emotional Punishment. We understand these results to hold a major implication for the design of the prevention strategies, in which the areas of priority clearly need special emphasis. Although the high levels of anxiety that lead to certain violent conduct could not be systematically equated with the low levels of tolerance, it is possible to use these results as an indicator of the levels of sensitising the youths towards such conditions. Diverse studies have analysed the effect of minimisation and/or normalisation of violent conduct in relationships with the risk of said relationship becoming abusive (Harned 2005; Hernando et al. 2012), with its association with the maintenance of this type of relationship (Dunham and Senn 2000; Rhatigan et al. 2011), and also with the disengagement from legal proceedings (Cala et al. 2016).

As shown in Table 2, in each and every group considered, women reported higher levels of distress compared to men, with marked statistical significance and levels of effect for the victims. This reasoning cannot be followed regarding Emotional Punishment among battered and abused victims where the ES is 0.42 . If the investigations were carried out according to gender, males would only show differences between groups in terms of Sexual Abuse within the NA and NPA groups. Consequently, it may be considered that the levels of distress, despite constituting a major source of differentiation between males and females, is in no way a means to discriminate or differentiate between the three categories of abuse considered within this study. In the case of women (cp), differences were only observed between the groups $\mathrm{A}$ and NA regarding Emotional Punishment and Instrumental Abuse, in the sense that the first group, A, presents a lower average than NA for each factor. 
In general, the absence of significant differences (confirmed by low ES levels) indicates that the levels of distress across both genders cannot be generically associated with the risk of suffering from abusive conduct. The pattern of levels of distress in men is very distinct from that in women: in the case of women, the NA group presents the highest levels of anxiety compared to the remaining groups (A and NPA); therefore, it can be considered that their self-perception may suppose a feeling of protection and sensitisation.

With relation to the three distinct perceptions of abuse that have been considered within this study (A, NA and NPA), the data indicates that women report higher levels of distress within each and every category as well as for every form of abuse. In this case, the difference obtained for Sexual victimization and that for Gender victimization are worthy of note. The highest discomfort differential of self-perception of abuse can be found in the line reported by Harned (2005), who found that women that perceive and classify a sexual experience as abusive are clear that in many ways (verbal, non-verbal and by using physical resistance) they had refused the sexual exchange and feel they had been physically forced to undergo the said sexual experience (Harned 2005; Kahn et al. 2003). However, those who do not perceive the situation as abusive believe they had not adequately expressed their nonconsent and had finally given in to the undesired sexual experience due to pressure or coercion. Victimization by gender also offers evidence that sexist beliefs have been overcome to a greater extent by women who could explain the higher level of discomfort expressed (Merino et al. 2010).

The level of tolerance in terms of perceived abuse (A, NA and NPA) follows a distinct pattern for males and females. The unease for men is mainly focused on Sexual Abuse, which males generally perceive as NA instead of NPA. This is to say that males within the NA group tolerate sexual violence less than those found in the category NPA.

This makes it clear that those males or females who do not perceive themselves as abused find it difficult to define aggressive behaviour as abusive (RodríguezFranco et al. 2012). These results, in turn, indicate a low level of discomfort in regard to abusive conduct of their partners, which can be found in the work of Leisring (2009), which informs us that violent acts have different effects on the victims, depending on whether they were committed by a man or by a woman. Women offer results that differ from those of men: firstly, because the diverse categories of self-perception of abuse, A, NA and NPA, already offer four different forms of victimization, Sexual, Physical, Emotional Punishment and Instrumental, and secondly, with respect to the self-perception of abuse by Emotional Punishment and Instrumental Abuse, where NA shows a significantly lower level of tolerance.

The reality of non-perceived abuse and a higher tolerance could explain why violence is associated with physical aggression; non-physical aggression is the most common form of abuse conducted in relationships of engaged couples while at the same time physically violent behaviour is assumed to take place in the background (Shorey et al. 2013). Other studies highlight that women suffer more injuries, including those resulting in death in cases of physically violent behaviour within the relationship (Muñoz-Rivas et al. 2007). According to Hernando et al. (2012), fear and insecurity are factors that facilitate maintaining an abusive relationship, and evidence also indicates that physical violence produces situations involving fear and/or injuries without ever being perceived as abusive (Muñoz-Rivas et al. 2007; Rodríguez-Franco et al. 2012).

The differences obtained in gender refer to a lower tolerance of violence within relationships involving engaged man-to-woman couples, thereby enabling a variable to be taken into account concerning the maintenance of the abusive relationship that depends on whether the abuse reduces or increases (Dunham and Senn 2000). Sánchez and Solís (2007), in line with our results, refer to the perception of violence being an unrecognised or neglected practise accompanied with attitudes of tolerance of abuse in that love forgives all.

From our data, levels of tolerance of various forms of victimization are different for males and females, with the category NA showing the highest levels of distress. The lowest levels of discomfort were expressed by males within the categories of non- perceived abuse, thereby implying a high level of tolerance regarding violent conduct within their relationships, and thus also supposing great risk. This was demonstrated when men were asked the question regarding consequences of aggression (slapping, shoving and punching) within a relationship. Notably, aggressive individuals expect positive consequences (such as winning an argument) and less negative consequences (such as ending the relationship) than non-aggressive individuals (Leisring 2009; Riggs and Caufield 1997).

This situation has been identified as a risk factor for the development of abusive relationships while such abusive conduct is considered 'normal' and 'expected' within relationships involving engaged couples (Connolly et al. 2010; McDonell et al. 2010) and that psychological aggression is a consistent predictor of the perpetration of physical violence in the future of such relationships (Baker and Stith 2008).

As has been reflected in previous publications (Rodríguez-Franco et al. 2012; Rodríguez-Franco et al. 2010), the general adolescent population cannot be 
classified as simply 'abused' or 'non-abused', but that solid evidence exists in regard to the formation of a new category, that of 'non-perceived abuse'. This new classification includes those people who show evidence of suffering from abusive behaviour but remain unaware that they themselves are being abused (Rodríguez-Franco et al. 2016).

With regard to tolerance, lack of knowledge concerning the determination of which factors could influence the vast majority of victims can be considered to be a major limitation. This limitation must be acknowledged in order to enable us to ascertain what determines an abusive situation within adolescent relationships and what types of situations are acceptable. These results can also be deemed as limited due to the lack of knowledge and understanding of attitudes that men and women have towards respecting the roles each one plays in general everyday life. Especially within relationships involving engaged couples, it is necessary to establish at which level an 'attitude' transcends into tolerance due to abuse. Furthermore, this study has not referred to the duration of a relationship, something we believe to be of major importance, since this study concerns adolescents experiencing victimization, and thus could lead to a lower probability of the victim accepting a conflictive relationship in the future.

\section{Acknowledgements}

This study formed part of a research project financed by AECID (CYTED) reference number: AP/035718/11

\section{Competing interests}

The authors declare that they have no competing interests.

\section{Authors' Contributions}

All the authors of the article undersigned have significantly contributed to its development: LCA and CEP have collected the sample and made the database, as well as they collaborated in the theoretical foundation; CBM and LRF performed statistical analyzes, interpretation of results and collaborative discussion. ÁAB and FJRD, performed collaborated on the theoretical foundation and conducted the discussion and participated in the interpretation of statistical data. The same authors have given their agreement, giving up all rights to it, if it is accepted for publication Psychology Journal: Reflexão e Critica. The authors express their agreement with the request for publication and the rate same. All authors read and approved the final manuscript.

\section{Author details}

${ }^{1}$ Universidad Autónoma de Yucatán, Mérida, México. ${ }^{2}$ Universidad de Extremadura, Cáceres, Spain. ${ }^{3}$ Universidad de Guadalajara, Guadalajara, México. ${ }^{4}$ Universidad de Sevilla, Sevilla, Spain. ${ }^{5}$ Universidad de Oviedo, Oviedo, Spain. ${ }^{6}$ Facultad de Psicología, Plaza Feijóo, s/n. Despacho 202, 33003 Madrid, Spain.

Received: 30 July 2016 Accepted: 14 October 2016

Published online: 28 November 2016

\section{References}

Anderson, M. L., \& Kobek-Pezzarossi, C. M. (2011). Is it abuse? Deaf female undergraduates' labelling of partner violence. Journal of Deaf Studies and Deaf Education, 17, 273-286

Antle, B. F Sullivan, D. J Dryden, A, Karam, E. A. \& Barbee, A. P. (2011). Healthy relationship education for dating violence prevention among high-risk youth. Children and Youth Services Review, 33, 173-179. doi:10.1016/j. childyouth.2010.08.031.

Arce, R., Fariña, F., \& Fraga, A. I. (2000). Género y formación de juicios en un caso de violación [Gender and juror judgment making in a case of rape]. Psicothema, 12, 623-628.

Arce, R., Fariña, F., \& Vilariño, M. (2015). Daño psicológico en casos de víctimas de violencia de género: Un estudio comparativo de las evaluaciones forenses [Psychological injury in intimate partner violence cases: a contrastive analysis of forensic measures]. Revista Iberoamericana de Psicología y Salud, 6, 72-80. doi:10.1016/j.rips.2015.04.002.

Baker, C. R., \& Stith, S. M. (2008). Factors predicting dating violence perpetration among male and female college students. Journal of Aggression Maltreatment and Trauma, 17, 227-244.

Cala, M. J., Trigo, M. E., \& Saavedra, F. J. (2016). Women's disengagement from legal proceedings for intimate partner violence: sociodemographic and psychological variables. European Journal of Psychology Applied to Legal Context, 8, 35-42. doi:10.1016/j.ejpal.2015.10.002.

Capaldi, D. M., Short, J. W., \& Kim, H. K. (2005). A life span developmental system perspective on aggression towards a partner. In W. M. Pinsof \& J. Lebow (Eds.), Family psychology: The art of the science (pp. 141-167). New York: Oxford University Press.

Cohen, J. (1988). Statistical power analysis for the behavioural sciences (2nd ed.). NJ, EEUU: Erlbaum

Cho, H., Velez-Ortiz, D., \& Parra-Cardona, J. R. (2014). Prevalence of intimate partner violence and associated risk factors among Latinos/as: an exploratory study with three Latino subpopulations. Violence Against Woman, 20, 1041-1058. doi:10.1177/1077801214549636.

Connolly, J., Friedlander, L., Pepler, D., Craig, W., \& Laporte, L. (2010). The ecology of demographic risk factors. Journal of Aggression Maltreatment and Trauma, 19, 469-491.

Cortés, A. M. L., Bringas, M. C., Rodríguez-Franco, L., Flores, G. M., Ramiro-Sánchez, T., \& Rodríguez-Díaz, F. (2014). Unperceived dating violence among Mexican students. International Journal of Clinical and Health Psychology, 14(1), 39-47.

Dunham, K., \& Senn, C. Y. (2000). Minimizing negative experiences: women's disclosure of partner abuse. Journal of Interpersonal Violence, 15, 251-261. doi:10.1177/088626000015003002.

ENDIREH. (2011). Panorama de violencia contra las mujeres en México. México: ENDIREH/Instituto Nacional de Estadística y Geografía.

ENVINOV. (2008). Encuesta nacional de violencia en el noviazgo. México: IMJ/INEGI.

Gómez, A. M. (2011). Testing the cycle of violence hypothesis: child abuse and adolescent dating violence as predictors of intimate partner violence in young adulthood. Youth \& Society, 43, 171-192.

Gómez, M., Delgado, A., \& Gómez, A. (2014). Violencia en relaciones de pareja de jóvenes y adolescentes. Revista Latinoamericana de Psicología, 46, 148-159.

González, J., Hernández, A., \& Garza, R. I. (2010). Modelo predictivo de las interacciones violentas en parejas jóvenes y prejuicios de género asociados. Revista Científica Electrónica de Psicología, 10, 224-239.

Gracia, E., Herrero, J., Lila, M., \& Fuente, A. (2010). Percepción y actitudes hacia la violencia de pareja contra la mujer en inmigrantes latinoamericanos en España. Intervención Psicosocial, 19, 135-144.

Harned, M. S. (2005). Understanding women's labelling of unwanted sexual experiences with dating partners: a qualitative analysis. Violence Against Women, 11, 374-413.

Hernando, G. A., García, R. A. D., \& Montilla, C. C. (2012). Exploración de las actitudes y conductas de jóvenes universitarios ante la violencia en las relaciones de pareja. Revista Complutense de Educación, 2, 427-441.

Kahn, A. S., Jackson, J., Kully, C., Badger, K., \& Halvorsen, J. (2003). Calling it rape: differences in experiences of women who do or do not label their sexual assault as rape. Psychology of Women Quarterly, 27, 233-242.

Leisring, P. A. (2009). What will happen if I punch him? Expected consequences of female violence against male dating partners. Journal of Aggression Maltreatment \& Trauma, 18(7), 739-751.

Lichter, E. L., \& McCloskey, L. A. (2004). The effects of childhood exposure to marital violence on adolescent gender-role beliefs and dating violence. Psychology of Women Quarterly, 28, 344-357.

Littleton, H., Axsom, D., \& Grills-Taquechel, A. (2009). Sexual assault victim's acknowledgement status and re-victimization risk. Psychology of Women Quarterly, 33, 34-42.

López-Cepero, J., Rodríguez-Franco, L., Rodríguez-Díaz, F. J., Bringas, C., \& Paíno, S. (2015). Percepción de la victimización en el noviazgo de adolescentes y jóvenes españoles. Revista Iberoamericana de Psicología y Salud, 6, 64-71. 
McDonell, J., Ott, J., \& Mitchell, M. (2010). Predicting dating violence, victimization and perpetration among middle school students in a rural southern community. Children and Youth Services Review, 32, 1458-1463.

Merino, V. E., Martínez-Arias, M. R., \& Díaz-Aguado, M. J. (2010). Sexismo, inteligencia emocional y adolescencia. Psicología Educativa, 16, 77-88. doi:10.5093/ed2010v16n1a7.

Muñoz-Rivas, M. J., Graña, J. L., O'Leary, K. D., \& González, M. P. (2007). Aggression in adolescent dating relationships: prevalence, justification, and health consequences. Journal of Adolescent Health, 40, 298-304. doi:10.1016/j. jadohealth.2006.11.137.

Mugoya, G., Witte, T., \& Ernst, K. (2015). Sociocultural and victimization factors that impact attitudes toward intimate partner violence among Kenyan women. Journal of Interpersonal Violence, 30, 2851-2871.

Novo, M., Herbón, J., \& Amado, B. G. (2016). Género y victimización: Efectos en la evaluación de la violencia psicológica sutil y manifiesta, apego adulto y tácticas de resolución de conflictos. Revista Iberoamericana de Psicología y Salud, 7, 89-97.

Ramírez, I. L., \& Smithey, M. (2008). Intimate partner violence victimization among Mexican university students: a descriptive study and analysis of demographic factors. Contemporany Issues in Criminology and the Social Sciences, 2(4), 34-53.

Rey-Anacona, C. A. (2013). Prevalencia y tipos de maltrato en el noviazgo en adolescentes y adultos jóvenes. Terapia Psicológica, 31, 143-154.

Rhatigan, D. L., Stewart, C., \& Moore, T. M. (2011). Effects of gender and confrontation on attributions of female-perpetrated intimate partner violence. Sex Roles, 64, 875-887. doi:10.1007/s11199-011-9951-2.

Riggs, D. S., \& Caufield, M. B. (1997). Expected consequences of male violence against their female dating partners. Journal of Interpersonal Violence, 12, 229-240.

Rodríguez-Franco, L., López-Cepero, J., López-Núñez, l., Paíno, S., Antuña, A., Bringas, C., \& Rodríguez-Díaz, F. J. (2016). Evolution of victimization, tolerance and detection of intimate partner violence among young Spanish women. Revista de Psicología Social, 31, 136-156.

Rodríguez-Franco, L., López-Cepero, J., Rodríguez, F. J., Bringas, C., Antuña, M. A., \& Estrada, C. (2010). Validación del Cuestionario de Violencia entre Novios (CUVINO) en jóvenes hispanohablantes: Análisis de resultados en España, México y Argentina. Anuario de Psicología Clínica y de la Salud, 6, 45-52.

Rodríguez-Franco, L., Antuña, M. A., López-Cepero, J., Rodríguez-Díaz, F., \& Bringas, M. C. (2012). Tolerance towards dating violence in Spanish adolescents. Psicothema, 24, 236-242

Rojas-Solís, J. L. (2013). Violencia en el noviazgo de adolescentes Mexicanos: Una revisión. Revista de Educación y Desarrollo, 27, 49-58.

Ruiz-Hernández, J. A., García-Jiménez, J. J., Llor-Esteban, B., \& Godoy-Fernández, C. (2015). Risk factors for intimate partner violence in prison inmates. European Journal of Psychology Applied to Legal Context, 7, 41-49. doi:10.1016/j.ejpal. 2014.11.003.

Sánchez, A. R., \& Solís, M. J. (2007). Estudiantes universitarios: percepción y vivencias de la sexualidad. Yucatán: IX Congreso Nacional de Investigación Educativa. Retrieved from http://www.comie.org.mx/congreso/memoriaelectronica/v09/ ponencias/at16/P RE1178980441.pdf.

Sears, H. A., Byers, E. S., \& Price, E. L. (2007). The co-occurrence of adolescent boys' and girls' use of psychologically, physically, and sexually abusive behaviours in their dating relationships. Journal of Adolescence, 30, 487-504. doi:10.1016/j.adolescence.2006.05.002.

Shorey, R. C., Febres, J., Brasfield, H., Zucosky, H., Cornelius, T. L., \& Stuart, G. L. (2013). Reactions to dating violence research: do difficulties with distress tolerance increase negative reactions? Journal of Family Violence, 28, 479-487.

Shorey, R., Seavey, A., Brasfield, H., Febres, J., File, P., \& Stuart, G. (2015). The moderating effect of social support from a dating partner on the association between dating violence victimization and adjustment. Violence Against Women, 21, 460-477.

Straus, M. A. (2004). Prevalence of violence against dating partners by male and female university students worldwide. Violence Against Women, 10, 790-811. doi:10.1177/1077801204265552.

Taft, C. T., Schumm, J., Orazem, R. J., Meis, L., \& Pinto, L. A. (2010). Examining the link between posttraumatic stress disorder symptoms and dating aggression perpetration. Violence and Victims, 25, 456-469. doi:10.1891/ 0886-6708.25.4.456

Whitaker, D. J., Le, B., \& Noilon, P. H. (2010). Persistence and desistance of the perpetration of physical aggression across relationships. Journal of Interpersonal Violence, 25, 591-609.

\section{Submit your manuscript to a SpringerOpen ${ }^{\mathcal{O}}$ journal and benefit from:}

- Convenient online submission

- Rigorous peer review

- Immediate publication on acceptance

- Open access: articles freely available online

- High visibility within the field

- Retaining the copyright to your article

Submit your next manuscript at $\gg$ springeropen.com 